\title{
Characterization of the global profile of genes expressed in cervical epithelium by Serial Analysis of Gene Expression (SAGE) Carlos Pérez-Plasencia1, Gregory Riggins², Guelaguetza Vázquez-Ortiz ${ }^{1}$, José Moreno $^{3}$, Hugo Arreola ${ }^{1}$, Alfredo Hidalgo ${ }^{1}$, Patricia Piña-Sanchez ${ }^{1}$ and Mauricio Salcedo*1
}

Address: ${ }^{1}$ Laboratorio de Oncología Genómica, Unidad de Investigación Médica en Enfermedades Oncológicas, Hospital de Oncología, CMN Siglo XXI-IMSS, Mexico, 2John Hopkins University, School of Medicine, Baltimore, MD, USA and ${ }^{3}$ Unidad de Investigación Médica en Enfermedades Autoinmunes, Hospital de Especialidades, CMN Siglo XXI-IMSS México

Email: Carlos Pérez-Plasencia - car_plas@yahoo.com; Gregory Riggins - griggin1@jhmi.edu; Guelaguetza Vázquez-Ortiz - guelav@yahoo.com; José Moreno - jmorenor@cis.gob.mx; Hugo Arreola - pearl_hugo@yahoo.com.mx; Alfredo Hidalgo - alfhm@yahoo.com; Patricia Piña-

Sanchez - patricia_1307@yahoo.com.mx; Mauricio Salcedo* - maosal89@yahoo.com

* Corresponding author

Published: 19 September 2005

BMC Genomics 2005, 6:130 doi:10.1186/147|-2/64-6-130
Received: 31 May 2005

Accepted: 19 September 2005

This article is available from: http://www.biomedcentral.com/I47I-2164/6/130

(c) 2005 Pérez-Plasencia et al; licensee BioMed Central Ltd.

This is an Open Access article distributed under the terms of the Creative Commons Attribution License (http://creativecommons.org/licenses/by/2.0), which permits unrestricted use, distribution, and reproduction in any medium, provided the original work is properly cited.

\begin{abstract}
Background: Serial Analysis of Gene Expression (SAGE) is a new technique that allows a detailed and profound quantitative and qualitative knowledge of gene expression profile, without previous knowledge of sequence of analyzed genes. We carried out a modification of SAGE methodology (microSAGE), useful for the analysis of limited quantities of tissue samples, on normal human cervical tissue obtained from a donor without histopathological lesions. Cervical epithelium is constituted mainly by cervical keratinocytes which are the targets of human papilloma virus (HPV), where persistent HPV infection of cervical epithelium is associated with an increase risk for developing cervical carcinomas (CC).
\end{abstract}

Results: We report here a transcriptome analysis of cervical tissue by SAGE, derived from 30,418 sequenced tags that provide a wealth of information about the gene products involved in normal cervical epithelium physiology, as well as genes not previously found in uterine cervix tissue involved in the process of epidermal differentiation.

Conclusion: This first comprehensive and profound analysis of uterine cervix transcriptome, should be useful for the identification of genes involved in normal cervix uterine function, and candidate genes associated with cervical carcinoma.

\section{Background}

One of the most frequent malignancies in women worldwide is the Uterine Cervical Carcinoma (CC), both in incidence and mortality and the first cause of death among the Mexican female population [1]. High-risk human papillomavirus (HPV) persistent infection is considered the most important risk factor associated with the development of this tumor $[2,3]$. Although HPV is a mandatory cause for $\mathrm{CC}$, it is not sufficient to trigger all the changes required for its development [4]. 
A number of recent studies about gene expression profiles in in vitro HPV-infected cultured keratinocytes and from (CC) clinical samples have provided an initial notion of the changes in gene expression induced by HPV and in early CC [5-10]. Moreover, some studies have compared normal versus tumor-induced gene expression in cervical samples with the aim to identify potential tumor markers of clinical value [11-13].

At present, there are reports of genes expressed by keratinocytes derived from a normal human epidermis and from mouse uterus carried out by Serial Analysis of Gene Expression (SAGE) [14-17]. However, no such study exists for human cervix. Therefore, the aim of our study was to describe the first compendium of expressed genes in normal cervical epithelium, which is composed mainly by keratinocytes strongly influenced by hormones. To achieve this we used SAGE, which is capable of producing an accurate molecular picture of cervical tissue based on expressed genes, as the main methodology. As SAGE is not dependent on preexisting databases of expressed genes, it provides an unbiased view of gene expression profiles within the mRNA populations [18]. SAGE allows the simultaneous quantitative and qualitative analysis of thousands of gene transcripts based on two principles: first, 14 mers are sufficient to uniquely identify $95 \%$ of cell transcripts [19]; and second, cloning of these $14 \mathrm{bp}$ tags serially with the insertion of a restriction enzyme recognition sequence as an anchor, the throughput is considerably increased. To obtain a catalog of expressed genes and their relative frequencies we performed database analysis to relate each tag to its corresponding gene [20]. As an important drawback of SAGE is that a large amount of messenger RNA (2.5-5 $\mu$ g polyA RNA) is required, and our tissue supply was limited (a punch biopsy) we employed the MicroSAGE protocol in RNA thereof [21]. The present report describes a partial transcriptome of a sample derived from normal cervical epithelium used to construct a SAGE library with 30,418 sequenced tags.

\section{Results and discussion \\ SAGE library derived from one normal uterine ectocervical sample}

Our Sage library was obtained from ectocervical tissue from a 38 year old healthy woman with active sexual life, not taking any hormonal therapy, nor any other drug that could potentially alter cervical physiology, we designated this as SAGE_cervix_normal_B_1. Histological analysis of this sample by $H \& E$ revealed normal ectocervical tissue, approximately $80 \%$ epithelium and $20 \%$ stroma without evidence of glands. There were minimal inflammatory infiltrates in the periphery of the sample, considered normal for this type of tissue.
The SAGE library yielded 30,418 sequenced tags, which was used to generate a table, which represents genes expressed in normal human cervix. For a complete list of the expressed genes, please visit the SAGEmap website, $[22,23]$. The derived catalog of expressed genes represents the first attempt to generate a comprehensive and profound analysis of the cervical epithelium expression profile. The wealth of information obtained allows detection of genes involved in normal epithelium physiology, as well as possible target genes of HPV infection. In general, tag frequency in a typical SAGE experiment follows a normal distribution $[24,25]$. Table 1 summarizes the general statistics of this library. As seen there is a normal distribution, where only a limited number of tags were either highly expressed or at an extremely low frequency (4.4 and $4.9 \%$, respectively). Tags with a frequency of 1 were not considered for quantitative purposes, because these are likely to represent artifacts of sequencing or of the SAGE procedure [26].

\section{Representativity of the data}

According to Zhang et al. [27], a study of SAGE data mining analysis of 300,000 tags, $75 \%$ of mRNA consists of transcripts expressed at more than five copies per cell, and, in general, transcripts are expressed at a range from one to 5,300 copies per cell. With this in mind, our 30,000-tag library, represents $10 \%$ of the total tags analyzed by Velculescu et al. The most frequently represented tag in the current report had a frequency of 515 (16,930 tags per million TPM). An estimate of such data indicates that this gene tag has an expression level of $\sim 5,150$ copies per cell, similar to what is observed in digital northerns of other top expressed tags in SAGE libraries (Figure 1A). We have to keep in mind, however, that in certain tissues, some genes are expressed at much higher levels, such as growth hormone, with 149,630 TPM in pituitary gland [28]. Because SAGE analysis represents a qualitative and quantitative assay of messenger RNA abundance not biased by cloning or polymerase chain reaction efficiency [29], our data provide an estimate of the genes normally expressed by normal uterine cervix.

Among the most frequently expressed tags in our library (Table 2), some corresponded to ubiquitously expressed transcripts (GRIN2C, FTH1, GNS, RPLP2, RPL21). The presence of this type of genes is a common result in SAGE experiments with an expected heterogeneity in their expression levels $[14,15,17,19]$, indicating a possible role as housekeeping genes (Figure 1B). In a report Velculescu et al., by means of data base analysis of SAGE libraries, found that $\sim 1,000$ genes are present in all normal or tumor tissues analyzed with over five copies per cell [30]. Hence, this list of genes identified by data mining is termed minimal transcriptome (i. e., the set of genes expressed by every cell), which represents genes constitu- 
Table I: SAGE data general statistics.

\begin{tabular}{|c|c|c|}
\hline Frequency distribution ${ }^{a}$ & Tags & Individual Genes ${ }^{b}$ \\
\hline$>200$ tags & I,348 (4.4\%) & $5(0.11 \%)$ \\
\hline $100-200$ tags & $2,37 \mid(7.8 \%)^{c}$ & $21(0.5 \%)^{d}$ \\
\hline $20-100$ tags & $5,536(18.19 \%)$ & $80(1.8 \%)$ \\
\hline $5-19$ tags & $6,349(20.8 \%)$ & $575(13.2 \%)$ \\
\hline $2-4$ tags & $13,316(43.7 \%)$ & $3,050(70.4 \%)$ \\
\hline I tag & 1,498 (4.9\%) & $609(14.1 \%)$ \\
\hline Total & $30,418(100 \%)$ & $4,340(100 \%)$ \\
\hline No of unique tags & & 8,062 \\
\hline Tags with SAGE database matches & & 5,255 \\
\hline No. of different transcripts matched & & 4,340 \\
\hline No of poorly characterized transcripts & & 1,215 \\
\hline Genes with known functione & & 2,453 \\
\hline
\end{tabular}

${ }^{a}$ Calculation of the frequency distributon of a given tag was based on total tags sequenced in library.

bSome genes have more than one tag, hence we search for individual genes in a database created in SQL language.

$c, d$ Percentage of tags or genes in frequency group.

ebased on FatiGO Datamining website [3I]

tively expressed. In supplementary information of Velculescu's work [30] a search for the minimal transcriptome in our library, indicates $>95 \%$ of housekeeping genes (data not shown), further validating the cervical library.

\section{Spectrum of genes expressed by normal cervical tissue}

To obtain better knowledge of the functional categories of global gene expression profile, we employed the Fatigo Data mining website [31,32]. Figure 2 shows the distribution of expressed genes by functional categories defined by the Gene Ontology Consortium. As seen, the most frequent individual transcripts correspond to genes involved in maintenance and basic metabolism. On the other hand, genes corresponding to other processes such as cell growth regulation, morphogenesis, cell differentiation, or death were not as frequently expressed.

Top expressed non-ubiquitous genes in normal cervical tissue mainly correspond to epithelial growth and differentiation

It was important to distinguish which non-ubiquitous genes were predominantly expressed in normal cervix. As seen in table 2, genes related with epithelial differentiation and squamous architectural maintenance are abundantly represented in our library. These include S100A8, S100A9, and SPRR3, that belong to a complex of genes that are subject to coordinate regulation during keratinocyte differentiation. This complex has been called the epidermal differentiation complex (EDC) and is located on the 1q21 chromosome [33,34]. These genes share spatial and temporal expression and interrelated functions and are grouped in three related gene families: cornified envelope precursor proteins (involucrin, loricrin, and the small proline-rich proteins [SPRRs]); intermediate filament-associated proteins (profilaggrin and trichohyalin), and calcium binding proteins (the S100As) [reviewed in [35]]. Approximately 30 genes belonging to the EDC are clustered together in a $200 \mathrm{Mb}$ region, from which there are 20 genes expressed the in cervical SAGE library (Table 3).

\section{End point RT-PCR analysis confirms expression of genes detected by SAGE}

It was important to confirm the expression of some EDC representative genes in different normal cervical tissues by a different technique. For this, we chose end point reverse transcriptase polymerase chain reaction (RT-PCR) analysis. Figure 3 shows the expression of five EDC genes in HPV negative tissue samples with no histopathologic lesion. As expected, the majority of cases expressed these genes. However, there were some differences in the level of expression among the different normal samples. This could be due to the fact that samples were taken on different days of the menstrual cycle (hormonal influence) or to unknown physiological differences among biological systems.

\section{Minor expression of fibroblast-related genes in cervical tissue}

The gene expression catalog reported on here was obtained from a heterogeneous population of cells composed mainly of epithelial keratinocytes in dissimilar 
A

\begin{tabular}{|c|c|c|c|c|c|}
\hline ibrary Name & $\mathrm{TPM}^{2}$ & $\mathrm{DN} \mathrm{N}^{b}$ & $\begin{array}{l}\text { Total } \\
\text { Tags }\end{array}$ & Gene ID & Tissue \\
\hline SAGE 95_347 & 15447 & & 67386 & OCA2 & Mammary gland carcinoma \\
\hline SAGE_cervix_normal_B1 & 16930 & & 30418 & S100A8 & Normal Ectocervix \\
\hline SAGE_BB542 whitematter & 16864 & & 94876 & S36112 & Normal brain, whitematter \\
\hline SAGE Duke post crisis fibroblasts & 19674 & & 22466 & RLP35 & Fibroblast derived from skin, cell line \\
\hline SAGE_White_Blood_Cells_normal & 13224 & & 31985 & RPS19 & Leukocytes, antibody purified \\
\hline SAGE_Breast_normal_stroma_AP & 11635 & & 79152 & MGC27165 & Normal breast stroma \\
\hline
\end{tabular}

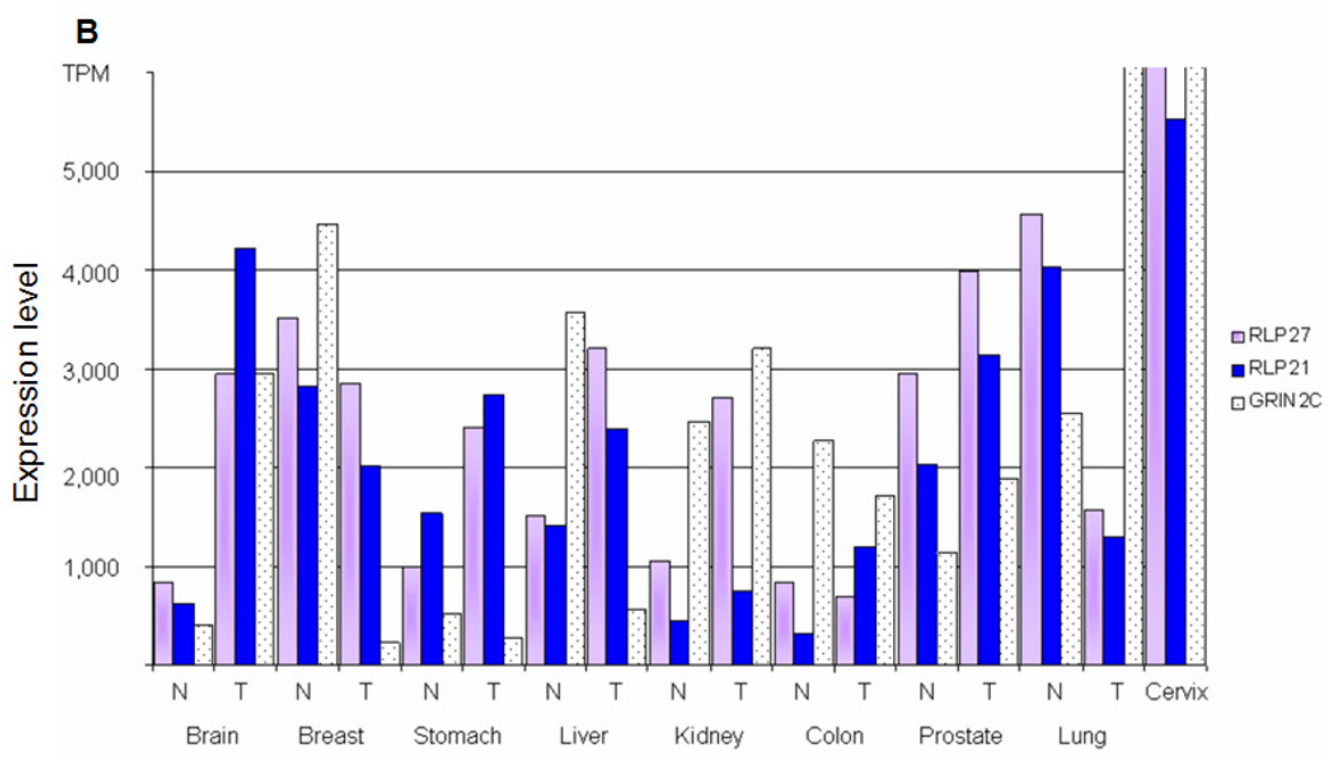

Figure I

A) Comparison of most expressed tags among different SAGE libraries. Normalized expression levels (TPM) are similar between libraries with different total sequenced tags, indicating comparable messenger abundance among top expressed genes. Expression levels were obtained from SAGEmap website http://wwwncbin/mnihgov/projects/SAGE/index

cgi?cmd=expsetup. ${ }^{a T P M: ~ T a g s ~ p e r ~ m i l l i o n . ~ N o r m a l i z a t i o n ~ t o ~ c o m p a r e ~ l i b r a r i e s ~ w i t h ~ d i f f e r e n t ~ n u m b e r s ~ o f ~ s e q u e n c e d ~ t a g s . ~ T P M ~}$ is obtained by the following formula [(Tag frequency) $(1000,000) /$ Total No. of sequenced tags]. ${ }^{b} \mathrm{DN}$ : digital northern, indicating gene expression level for a specific gene in a library. B. Graphical representation of expression levels (TPM) for three constitutive genes in several normal $(\mathbf{N})$ and tumoral $(T)$ tissues. Brain tissue libraries: SAGE BB542 whitematter $(N)$ and SAGE Brain medulloblastoma B 9804 PII7 (T). Breast: SAGE Breast normal organoid (N) and B SAGE Breast carcinoma epithelium AP DCIS6 (T). Gastric: SAGE normal gastric body epithelial (N) and SAGE Hiroshima GC W246T (T). Liver: SAGE normal liver $(\mathrm{N})$ and SAGE Liver cholangiocarcinoma B K2D (T). Kidney: SAGE Duke Kidney $(\mathrm{N})$ and

SAGE_Kidney_carcinoma_B_D2 (T). Colon: SAGE NC2 (N) and SAGE Tu98 (T). Prostate: SAGE PR317 normal prostate (N) SAGE PR3 I7 prostate tumor (T). Lung: SAGE normal lung $(N)$ and SAGE Lung adenocarcinoma MD LIO (T). Expression levels are indicated as tags per million.

differentiation stages (basale, spinosum and granulosum strata). Nevertheless, these tissues also contain fibroblasts associated with connective, besides other minor cell populations. To know which genes are related to fibroblasts, we compared a SAGE library derived from neonatal foreskin primary fibroblasts (Agnes Baross, British Columbia Genome Sciences Centre). We found 923 gene tags shared by both libraries, which could due to the presence of fibroblasts in the Cervix SAGE library (supplementary information). Shared genes with known biological function reveal that processes as signal transduction, regulation of transcription and cell adhesion are mainly involved. We consider important to identify minor contributions to global gene expression profile in a heterogeneous cell population; however, it is important to note that unknown differences between cervical and neonatal foreskin fibroblasts could exist. 
Table 2: Top 20 expressed genes in normal cervical tissue.

\begin{tabular}{|c|c|c|c|c|c|c|}
\hline Tag sequence & Tags & $\mathrm{TPM}^{a}$ & UniGene ID & Gene & Cluster name & Biological Function ${ }^{b}$ \\
\hline TACCTGCAGA & 515 & 16930 & Hs.4I6073 & SIOOAB & SI00 calgranulin A & $\begin{array}{c}\text { Regulation of cell cycle } \\
\text { progression and differentiation. }\end{array}$ \\
\hline TAGGTTGTCT & 356 & 11703 & Hs.374596 & TPTI & $\begin{array}{l}\text { Tumor protein, translationally- } \\
\text { controlled I }\end{array}$ & Unknown \\
\hline TTTCCTGCTC & 276 & 9073 & Hs. 139322 & SPRR3 & Small proline-rich protein 3 & $\begin{array}{c}\text { Cross-linked envelope protein } \\
\text { of keratinocytes }\end{array}$ \\
\hline GAGGGAGTTT & 201 & 6607 & Hs.523463 & RPL27A & Ribosomal protein L27a & $\begin{array}{l}\text { Component of the ribosomal } \\
60 \text { S subunit }\end{array}$ \\
\hline GTGACCACGG & 188 & 6180 & Hs.436980 & GRIN2C & $\begin{array}{c}\text { Glutamate receptor, } \mathrm{N} \text {-methyl } \\
\text { D-aspartate } 2 \mathrm{C}\end{array}$ & lonotropic glutamate receptor \\
\hline GTGGCCACGG & 184 & 6049 & Hs.II 2405 & SIOOA9 & $\begin{array}{l}\text { SI00 calcium binding protein A9 } \\
\text { (calgranulin B) }\end{array}$ & $\begin{array}{c}\text { Regulation of cell cycle } \\
\text { progression and differentiation. }\end{array}$ \\
\hline GGGCTGGGGT & 173 & 5687 & $\begin{array}{l}\text { Hs. } 425125 \\
\text { Hs. } 90436\end{array}$ & RPL29; SPAG7 & $\begin{array}{l}\text { Ribosomal protein L29; Sperm } \\
\text { associated antigen } 7\end{array}$ & $\begin{array}{l}\text { Component of the ribosomal } \\
60 \mathrm{~S} \text { subunit. }\end{array}$ \\
\hline GCATAATAGG & 168 & 5523 & Hs.38II23 & RPL2I & Ribosomal protein L2I & $\begin{array}{l}\text { Component of the ribosomal } \\
60 \mathrm{~S} \text { subunit. }\end{array}$ \\
\hline TCAGATCTTT & 161 & 5292 & Hs.446628 & RPS4X & Ribosomal protein S4, X-linked & $\begin{array}{l}\text { Component of the ribosomal } \\
40 \mathrm{~S} \text { subunit. }\end{array}$ \\
\hline GTTGTGGTTA & 155 & 5095 & Hs.99785 & & FLJ21 245 & Unknown \\
\hline GGATTTGGCC & $15 \mid$ & 4964 & Hs.437594 & RPLP2 & Ribosomal protein, large P2 & $\begin{array}{l}\text { Component of the ribosomal } \\
60 \mathrm{~S} \text { subunit. }\end{array}$ \\
\hline TTGGGGTTTC & 143 & 4701 & Hs.448738 & FTHI & Ferritin, heavy polypeptide I & $\begin{array}{l}\text { Important for iron homeostasis, } \\
\text { stores iron in a soluble, } \\
\text { nontoxic, readily available form. }\end{array}$ \\
\hline TTGGTCCTCT & 138 & 4536 & Hs.38II72 & RPL4I & Rribosomal protein L4I & $\begin{array}{l}\text { Component of the ribosomal } \\
60 \mathrm{~S} \text { subunit. }\end{array}$ \\
\hline TGCACGTTTT & 130 & 4273 & Hs.265I74 & RPL32 & Ribosomal protein L32 & $\begin{array}{l}\text { Component of the ribosomal } \\
60 \mathrm{~S} \text { subunit. }\end{array}$ \\
\hline ACAAAGCATT & 128 & 4208 & Hs.369982 & IGFBP5 & $\begin{array}{l}\text { Insulin-like growth factor } \\
\text { binding protein } 5\end{array}$ & $\begin{array}{l}\text { IGF-binding proteins prolong } \\
\text { the half-life of the IGFs and have } \\
\text { been shown to either inhibit or } \\
\text { stimulate the growth promoting } \\
\text { effects of the IGF on cell } \\
\text { culture. }\end{array}$ \\
\hline AGGGCTTCCA & 122 & 4010 & Hs.40I929 & RPLIO & Ribosomal protein LIO & $\begin{array}{l}\text { Component of the ribosomal } \\
60 \mathrm{~S} \text { subunit. }\end{array}$ \\
\hline CСАCTGCACT & 114 & 3747 & Hs. 107003 & $C C N B I I P I$ & Cyclin BI interacting protein I & $\begin{array}{l}\text { Functions in progression of the } \\
\text { cell cycle through } G(2) / M \text {. }\end{array}$ \\
\hline GGCAAGCCCC & 107 & 3517 & Hs. 148340 & RPLIOA & ribosomal protein $\mathrm{LIOa}$ & $\begin{array}{l}\text { Component of the ribosomal } \\
60 \mathrm{~S} \text { subunit. }\end{array}$ \\
\hline CTGGGTTAAT & 105 & 3451 & Hs.334534 & GNS & $\begin{array}{l}\text { Glucosamine }(\mathrm{N} \text {-acetyl)-6- } \\
\text { sulfatase }\end{array}$ & $\begin{array}{l}\text { Lysosomal enzyme found in all } \\
\text { cells. It is involved in the } \\
\text { catabolism of heparin, heparan } \\
\text { sulphate, and keratan sulphate. }\end{array}$ \\
\hline TGCACTTCAA & 103 & 3386 & Hs.62886 & SPARCLI & SPARC-like I (mast9, hevin) & Calcium ion binding \\
\hline
\end{tabular}

aTPM: Tags per million; [(Tag frequency) $(1000,000) /$ Total No of sequenced tags].

bBiological function obtained from SOURCE, at http://smd.stanford.edu/cgi-bin/source/sourceSearch

\section{Conclusion}

To our knowledge, this is the first effort to achieve a global profile of gene expression in normal cervical tissue. This was accomplished by means of a methodology that produced an accurate catalog of expressed genes in this tissue. Analysis of gene expression revealed genes involved in keratinocyte differentiation. These genes have not been detected in cervical epithelium by traditional methodolo- gies such as RT-PCR or in situ hybridization. Although our SAGE library was derived from a single donor, the majority of samples analyzed expressed the genes selected, indicating reproducibility in human samples. SAGE methodology is a complex and expensive analysis mainly due to the great sequencing efforts required to achieve SAGE libraries. Nevertheless, the overwhelming information derived from these justifies the effort and provides 


\section{Functional category \\ Metabolism \\ Cellular physiological process \\ Cell communication \\ Response to stimulus \\ Regulation of physiology process \\ Organismal physiology process \\ Morphogenesis \\ Regulation of cellular process \\ Death \\ Cell differentiation}

Percentage of genes involved ${ }^{a}$

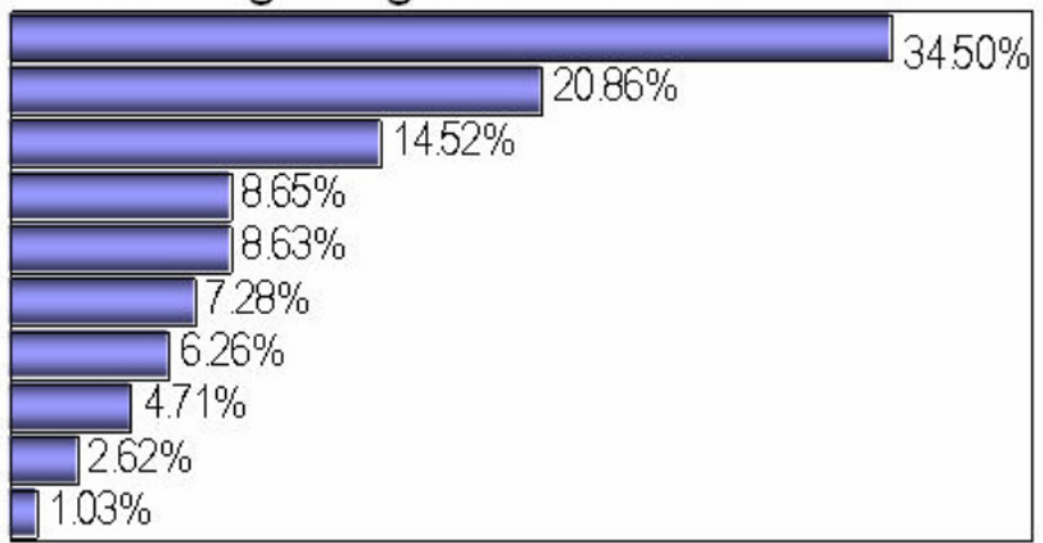

Figure 2

Functional categories assigned to individual genes identified in normal cervical SAGE library. Genes can be assigned in different functional categories. ${ }^{a}$ The percentage was calculated with 3,764 initial genes from which 2,720 genes had Gene Ontology classification.

Table 3: Genes belonging to Iq2I epidermal differentiation complex (EDC) expressed in cervical tissue

\begin{tabular}{|c|c|c|c|c|c|}
\hline TAG Sequence & TAGS & TPM $^{a}$ & UniGene ID & Gene ID & Gene name \\
\hline TACCTGCAGA & 515 & 16930 & Hs.416073 & SIOOA8 & SI 00 calcium binding protein $A 8$ \\
\hline TTTCCTGCTC & 276 & 9073 & Hs. 139322 & SPRR3 & Small proline-rich protein 3 \\
\hline GTGGCCACGG & 184 & 6049 & Hs. II 2405 & SIOOA9 & SI00 calcium binding protein A9 \\
\hline GATCAGGCCA & 18 & 591 & Hs.275243 & SIOOA6 & SI00 calcium binding protein $\mathrm{A} / 2$ \\
\hline GATCTCTTGG & 17 & 558 & Hs.38991 & SIOOA2 & S100 calcium binding protein $\mathrm{A} 2$ \\
\hline AGCAGATCAG & 15 & 493 & Hs.400250 & SIOOAIO & SI00 calcium binding protein $\mathrm{Al} 0$ \\
\hline CGTGGGACAC & 12 & 394 & Hs.l10196 & NICE-I (Clorf42) & Chromosome I open reading frame 42 \\
\hline CAGGCCCCAC & 12 & 394 & Hs.417004 & SIOOAII & SI00 calcium binding protein AII \\
\hline ATGTGTAACG & 8 & 263 & $\mathrm{Hs} .81256$ & SIOOA4 & SI 00 calcium binding protein A4 \\
\hline GAGCAGCGCC & 7 & 230 & Hs. II 2408 & S100A7 & SI 00 calcium binding protein $A 7$ \\
\hline ATGATCCCTG & 7 & 230 & Hs.355542 & SPRR2A & Small proline-rich protein $2 \mathrm{~A}$ \\
\hline TTGTGATGTA & 7 & 230 & Hs.85844 & TPM3 & Tropomyosin 3 \\
\hline TTCССТTACC & 6 & 197 & Hs.244349 & LCE3D & Late cornified envelope 3D \\
\hline GTCAGGGGAT & 5 & 164 & Hs. $|234|$ & ADARI & ADAR Adenosine deaminase, RNA-specific \\
\hline CCCTTGAGGA & 5 & 164 & Hs. 1076 & $S P R R I B$ & Small proline-rich protein IB (cornifin) \\
\hline CCCAGATGAT & 4 & 131 & Hs.7854 & SLC39AI & $\begin{array}{c}\text { Solute carrier family } 39 \text { (zinc transporter), } \\
\text { member I }\end{array}$ \\
\hline AACCCTAAAA & 2 & 65 & Hs.75II7 & ILF2 & Interleukin enhancer binding factor $2,45 \mathrm{kDa}$ \\
\hline GCAAATTTGA & 2 & 65 & Hs.6396 & JTB & Jumping translocation breakpoint \\
\hline CAAGGATCTA & 2 & 65 & Hs.355906 & NICE-3 (Clorf43) & Chromosome I open reading frame 43 \\
\hline CAAGGATCTA & 2 & 65 & Hs.49055I & UBAP2L (NICE-4) & Ubiquitin associated protein 2-like \\
\hline AGCCACTGCA & 2 & 65 & Hs.516439 & $I V L$ & Involucrin \\
\hline
\end{tabular}

aTPM: Tags per million.

better knowledge of cervical biology and physiology. In a near future, it could also provide an insight of cervical physiology or HPV infection and in other pathologies affecting cervical tissue.

\section{Methods}

\section{Tissues}

Normal cervices were obtained from women with negative Pap smears, confirmed by histopathological analysis, attending at the Dysplasia Clinic at General Hospital of Mexico, SS who had been subjected to hysterectomy due 


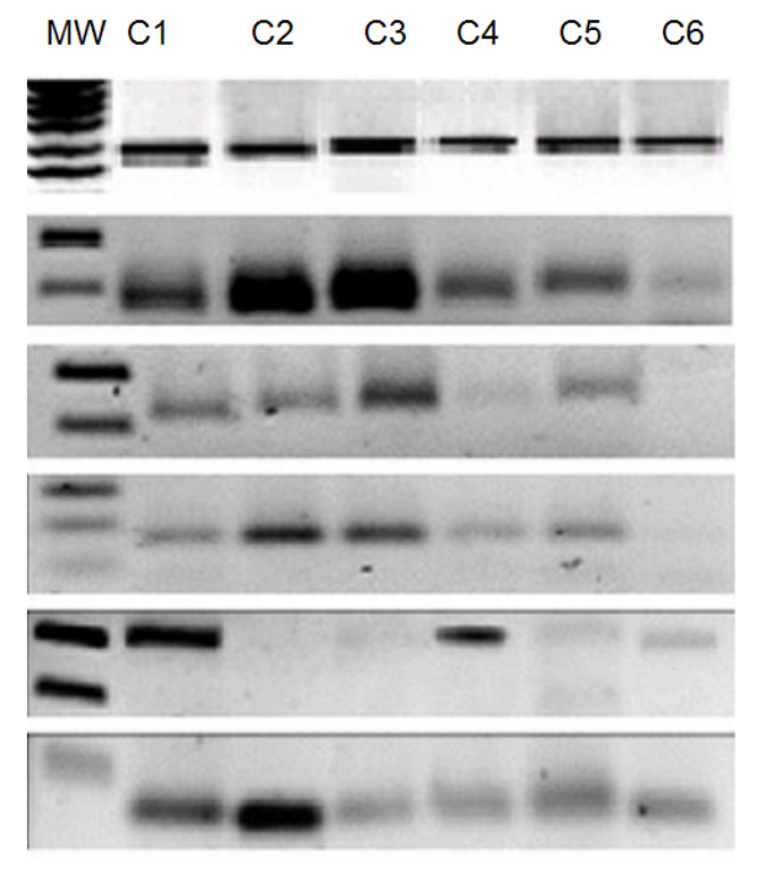

\section{GAPDH: Glyceraldehyde-3-phosphate dehydrogenase}

S100A8: S100 calcium binding protein A8 (calgranulin A)

S100A9: S100 calcium binding protein A9 (calgranulin B)

SPRR3: Small proline-rich protein 3

NICE-3: Chromosome 1 open reading frame 43

UBAP2L (NICE-4) : Ubiquitin associated protein 2-like

\section{Figure 3}

Expression of genes clustered in Iq2I, in normal cervical tissues. One hundred nanograms of total RNA purified of each sample was used in one RT-PCR reaction with gene specific primers; then one tenth of each RT-PCR reaction was subjected to agarose gel electrophoresis. MW: molecular weight marker; $\mathrm{Cl}-\mathrm{C} 6$ six different normal cervical samples

to uterine myomatosis. All patients were in reproductive age and none of them received hormonal therapy or contraceptives. All the described procedures were evaluated and approved by the local ethics committee of the Mexican Institute of Social Security. Written informed consent was obtained from all the patients. All tissue samples were longitudinally divided in three sections, the central part was snapped frozen in liquid nitrogen and stored at $-70^{\circ} \mathrm{C}$ until nucleic acid extraction, and the other two were fixed overnight in $70 \%$ ethanol and were paraffin embedded at the Department of Pathology, Oncology Hospital,
National Medical Center SXXI, Mexico. Serial sections from these fractions stained by Haematoxilin/ Eosin were inspected for representativity of the tissue.

\section{HPV detection and typing}

Genomic DNA was extracted from the phenol phase left by the TRIzol reagent (Gibco BRL, USA) RNA isolation protocol and amplified by PCR with MY11/MY09 primers [36] (Table 4). PCR products were separated by electrophoresis on 1\% agarose gel. Only HPV negative samples were included in this study.

Table 4: Oligonucleotides sequences used in this work.

\begin{tabular}{|c|c|c|c|c|c|}
\hline Gene & Sense $\left(5^{\prime} \rightarrow 3^{\prime}\right)$ & Antisense $\left(5^{\prime} \rightarrow 3^{\prime}\right)$ & $\begin{array}{c}\text { Annealing } \\
\text { temperature }\left({ }^{\circ} \mathrm{C}\right)^{a}\end{array}$ & $\begin{array}{l}\text { Product size } \\
\text { (bp) }\end{array}$ & Reference \\
\hline $\mathrm{HPV}^{*}$ & GCMCAGGGWCATAAYAATGG & CGTCCMARRGGAWACTGATC & 55 & 450 & {$[36]$} \\
\hline $\mathrm{S} 100 \mathrm{~A} 8$ & ATGCCGTCTACAGGGATGAC & ACGCCCATCTTTATCACCAG & 58 & 160 & This paper \\
\hline SI00 A9 & TCAGCTGGAACGCAACATAGA & TCAGCTGCTTGTCTGCATT & 56 & 205 & This Paper \\
\hline SPRR3 & TTCCACAACCTGGAAACACA & TTCAGGGACCTTGGTGTAGC & 55 & 174 & This paper \\
\hline NICE-3 & ACGGCTATGAAACAGCCCGCTA & GCACATTGCAACTGACTGGCTT & 57 & 330 & This paper \\
\hline NICE-4 & ACGGAATCCAATGAGGAAGGCA & TCAGTATTGGCTGGCTCTGCAT & 57 & 294 & This paper \\
\hline GAPDH & CATCTCTGCCCССTCTGCTGA & GGATGACCTTGCCCACAGCCT & 60 & 205 & [38] \\
\hline
\end{tabular}

${ }^{a} \mathrm{Tm}$ was calculated using primerquest program from [39]; however, it was necessary to adjust Tm in some cases. 


\section{Micro SAGE protocol}

Micro SAGE was performed according to Datson et al. [21] with minor modifications, by means of the Invitrogen's ISAGE kit (Invitrogen, San Diego, CA USA). RNA isolation was done in TRIzol according to manufacturer's instructions. Five $\mu \mathrm{g}$ of total RNA was used as input material. A heating step was introduced at $65^{\circ} \mathrm{C}$ for 10 minutes followed by 2 minutes on ice to allow a better separation of concatenamers [37]. Products greater than $300 \mathrm{bp}$ and smaller than 2,000 bp were excised, extracted and cloned in the SphI site of pZero vector. Clones were selected and screened for inserts by PCR. Cervix library was sequenced by Agencourt through SAGE sequencing service (CGAP collaboration, GR). Sequence files were analyzed with the SAGE300 software $[18,20]$, which identifies the anchoring enzyme sites and extracts the two tags flanked by NlaIII site. Gene identity and UniGene cluster assignment of each SAGE tag was obtained by using the tag-to-gene "reliable" map, from SAGEmap NCBI site [22,23]. The tags extracted were uploaded to SAGEmap and corresponding accession numbers were retrieved using the $H$. sapiens NCBI-GenBank database.

\section{Reverse Transcription-Polymerase Chain Reaction (RT- PCR) analysis}

Total RNA was extracted from six normal cervical tissues using TRIzol, quantified by densitometric analysis and its quality evaluated by denaturing gel electrophoresis. Contaminiating DNA was digested and removed with Rnasefree Dnase (Promega). Expression analysis was performed using $100 \mathrm{ng}$ total RNA in a RT-PCR reaction (Access RTPCR System, Promega). The mRNA was reverse-transcribed at $48^{\circ} \mathrm{C}$ for $45 \mathrm{~min}$. After an initial denaturation at $94^{\circ} \mathrm{C}$ for 2 minutes, the double stranded cDNA synthesized was amplified for 40 cycles with denaturation at $94^{\circ} \mathrm{C}$ for 30 seconds, annealing at $54-60^{\circ} \mathrm{C}$ for 1 minute and extension at $70^{\circ} \mathrm{C}$ for 2 minutes with specific oligonucleotides (Table 4) in a Perkin Elmer 480 Thermocycler.

Sense and antisense sequence of oligonucleotides for S100 A8 and 9, SPRR3, NICE-3 and -4 genes were designed with the program Primerquest [38]. GAPDH gene expression was used as an internal control.

\section{Competing interests}

The author(s) declare that they have no competing interests.

\section{Authors' contributions}

C.P.P. carried out the microSAGE protocol, real time RTPCR validations, the bioinformatics analysis and writing the manuscript. G.R. provided sequencing of SAGE library. J.M. helped to write the manuscript and participated in discussions. H.G. A.H. and P.P.S. helped for the bioinformatics analysis and database comparisons. M.S. is the principal investigator and was involved in the conceptualization, design and writing of the manuscript. All authors read and approved the final manuscript.

\section{Additional material}

\section{Additional data file 1}

Tags shared between fibroblast and cervix. Tags founded in SAGE_cervix_normal_B_1(30418 tags) BJ dermal fibroblasts (57573 tags) and SAGE_cervix_normal_B_1 (30418 tags). Ubiquous tags were deleted in both libraries. BJ dermal fibroblast library was derived from neonatal foreskin primary fibroblasts cultured in Ham's F10 medium supplemented with $10 \%$ fetal bovine serum, $100 \mathrm{U} / \mathrm{ml}$ penicillin, and 100 ug/ml streptomycin. Library was developed by Agnes Baross at British Columbia Genome Sciences Centre. Columns are: Gene TAG, Cluster ID and Gene Name

Click here for file

[http://www.biomedcentral.com/content/supplementary/14712164-6-130-S1.xls]

\section{Acknowledgements}

This work was partially supported by grants of CONACyT (F7I I4 and 34686-M, MS), and FOFOI-IMSS (MS). For the sequencing of SAGE library, funding was provided by the National Cancer Institute's Cancer Genome Anatomy Project (NIH 23XS073 and 24XS070, GR). During this work CPP, GVO, PPS were recipients of CONACYT, DGEP-UNAM and IMSS fellowships.

This work was submitted in partial fulfilment of the requirements for the $D$. SC. degree in for PPC at DOCTORADO EN CIENCIAS BIOMEDICAS, UNIVERSIDAD NACIONAL AUTONOMA DE MEXICO.

\section{References}

I. Mexican Ministry of Health: Registro Histopatológico de Neoplasias Malignas, Compendio de mortalidad y morbilidad. Secretaría de Salud, México; 1998.

2. Schiffman MH, Bauer HM, Hoover RN, Glass AG, Cadell DM, Rush BB, Scott DR, Sherman ME, Kurman RJ, Wacholder S: Epidemiologic evidence showing that human papillomavirus infection causes most cervical intraepithelial neoplasias. J Natl Cancer Inst 1993, 85:958-964.

3. Villa L: Human papillomaviruses and cervical cancer. Adv Cancer Res 1997, 71:321-341.

4. Franco EL, Rohan TE, Villa LL: Epidemiologic evidence, human papillomavirus infection as a necessary cause of cervical cancer. J Natl Cancer I 1999, 91:506-5I I.

5. Ruutu M, Peitsaro $P$, Johansson B, Syrjanen S: Transcriptional profiling of a human papillomavirus 33-positive squamous epithelial cell line which acquired a selective growth advantage after viral integration. Int / Cancer 2002, 100:3 I8-326.

6. Duffy CL, Phillips SL, Klingelhutz AJ: Microarray analysis identifies differentiation-associated genes regulated by human papillomavirus type 16 E6. Virology 2003, 3 14:196-205.

7. Thomas JT, Oh ST, Terhune SS, Laimins LA: Cellular changes induced by low-risk human papillomavirus type II in keratinocytes that stably maintain viral episomes. J Virol 200I, 75:7564-757I.

8. Garner-Hamrick PA, Fostel JM, Chien WM, Banerjee NS, Chow LT, Broker TR, Fisher C: Global effects of human papillomavirus type 18 E6/E7 in an organotypic keratinocyte culture system. J Virol 2004, 78:904I-9050.

9. Toussaint-Smith E, Donner DB, Roman A: Expression of human papillomavirus type $16 \mathrm{E} 6$ and E7 oncoproteins in primary 
foreskin keratinocytes is sufficient to alter the expression of angiogenic factors. Oncogene 2004, 23:2988-2995.

10. Nees M, Geoghegan JM, Hyman T, Frank S, Miller L, Woodworth CD: Papillomavirus type 16 oncogenes downregulate expression of interferon-responsive genes and upregulate proliferationassociated, NF-kappaB-responsive genes in cervical keratinocytes. J Virol 200I, 75:4283-4296.

II. Chen Y, Miller C, Mosher R, Zhao X, Deeds J, Morrissey M, Bryant B, Yang D, Meyer R, Cronin F, Gostout BS, Smith-McCune K, Schlegel $R$ : Identification of cervical cancer markers by cDNA and tissue microarrays. Cancer Res 2003, 63:1927-1935.

12. Shim C, Zhang W, Rhee $\mathrm{CH}$, Lee $\mathrm{JH}$ : Profiling of differentially expressed genes in human primary cervical cancer by complementary DNA expression array. Clin Cancer Res 1998, 4:3045-3050.

13. Vazquez-Ortiz G, Pina-Sanchez P, Vazquez K, Duenas A, Taja L, Mendoza P, Garcia JA, Salcedo M: Overexpression of cathepsin $f$ matrix metalloproteinases II and I 2 in cervical cancer. $B M C$ Cancer 2005, 5:68

14. van Ruissen F, Jansen BJ, de Jongh G], Zeeuwen PL, Schalkwijk J: A partial transcriptome of human epidermis. Genomics 2002, 79:67I-678

15. van Ruissen F, Jansen BJ, de Jongh GJ, van Vlijmen-Willems IM, Schalkwijk J: Differential gene expression in premalignant human epidermis revealed by cluster analysis of serial analysis of gene expression (SAGE) libraries. FASEB J 2002, 16:246-248.

16. Jansen BJ, van Ruissen F, de Jongh G, Zeeuwen PL, Schalkwijk J: Serial analysis of gene expression in differentiated cultures of human epidermal keratinocytes. J Invest Dermatol 200I, I 1 6: 12-22.

17. Larose M, St-Amand J, Yoshioka M, Belleau P, Morissette J, Labrie C Raymond $V$, Labrie F: Transcriptome of mouse uterus by serial analysis of gene expression (SAGE): comparison with skeletal muscle. Mol Reprod Dev 2004, 68: 142- 148.

18. Velculescu VE, Zhang L, Zhou W, Vogelstein J, Basrai MA, Bassett DE $\mathrm{Jr}$, Hieter $\mathrm{P}$, Vogelstein $\mathrm{B}$, Kinzler $\mathrm{KW}$ : Characterization of the yeast transcriptome. Cell 1997, 88:243-25I.

19. Dinel S, Bolduc C, Belleau P, Boivin A, Yoshioka M, Calvo E, Piedboeuf B, Snyder EE, Labrie F, St-Amand J: Reproducibility, bioinformatic analysis and power of the SAGE method to evaluate changes in transcriptome. Nucleic Acids Res 2005, 33:e26.

20. Velculescu V, Zhang L, Vogelstein B, Kinzler K: Serial analysis of gene expression. Science 1995, 270:484-487.

21. Datson N, Perk-de Jong J, van den Berg M, de Kloet E, Vreugdenhil E: MicroSAGE: a modified procedure for serial analysis of gene expression in limited amounts of tissue. Nucleic Acids Res 1999 , 27:1300-1307.

22. SAGEmap NCBI [http://www.ncbi.nih.gov/SAGE]

23. Lash AE, Tolstoshev CM, Wagner L, Schuler GD, Strausberg RL, Riggins G], Altschul SF: SAGEmap: a public gene expression resource. Genome Res 2000, 10:1051-1060.

24. Audic S, Claverie JM: The Significance of Digital Gene Expression Profiles. Genome Res 1997, 7:986-995.

25. Ruiiter JM, Van Kampen AH, Baas F: Statistical evaluation of SAGE libraries: consequences for experimental design. Physiol Genomics 2002, II:37-44

26. Yamamoto M, Wakatsuki T, Hada A, Ryo A: Use of serial analysis of gene expression (SAGE) technology. I Immunol Methods 200I, 250:45-66.

27. Zhang L, Zhou W, Velculescu VE, Kern SE, Hruban RH, Hamilton SR, Vogelstein B, Kinzler KW: Gene expression profiles in normal and cancer cells. Science 1997, 276:1268-1272.

28. Nishida $Y$, Yoshioka M, St-Amand J: The top 10 most abundant transcripts are sufficient to characterize the organs functional specificity: evidences from the cortex, hypothalamus and pituitary gland. Gene 2005, 344:|33-|4|

29. Polyak K, Riggins G]: Gene Discovery Using the Serial Analysis of Gene Expression Technique: Implications for Cancer Research. J Clin Oncol 200I, 19:2948-2958.

30. Velculescu VE, Madden SL, Zhang L, Lash AE, Yu J, Rago C, Lal A Wang CJ, Beaudry GA, Ciriello KM, Cook BP, Dufault MR, Ferguson AT, Gao Y, He TC, Hermeking H, Hiraldo SK, Hwang PM, Lopez MA, Luderer HF, Mathews B, Petroziello JM, Polyak K, Zawel L, Kinzler KW: Analysis of human transcriptomes. Nat Genet 1999, 23:387-388.

31. Fatigo Data mining [http://fatigo.bioinfo.cnio.es]
32. Al-Shahrour F, Díaz-Uriarte R, Dopazo J: FatiGO: a web tool for finding significant associations of Gene Ontology terms to groups of genes. Bioinformatics 2004, 20:578-580.

33. Marenholz I, Volz A, Ziegler A, Davies A, Ragoussis I, Korge BP, Mischke $D$ : Genetic analysis of the epidermal differentiation complex (EDC) on human chromosome Iq2 I: chromosomal orientation new markers a 6-Mb YAC contig. Genomics 1996, 37:295-302

34. Elder JT, Zhao X: Evidence for local control of gene expression in the epidermal differentiation complex. Exp Dermatol 2002, I I:406-4I2

35. Williams RE, Broad S, Sheer D, Ragoussis J: Subchromosomal Positioning of the Epidermal Differentiation Complex (EDC) in Keratinocyte Lymphoblast Interphase. Nuclei Exp Cell Res 2002, 272:163-175.36.

36. Resnick RM, Cornelissen MT, Wright DK, Eichinger GH, Fox HS, ter Schegget J, Manos MM: Detection and typing of human papillomavirus in archival cervical cancer specimens by DNA amplification with consensus primers. J Natl Cancer Inst 1990, 82: I477-| 484

37. Kenzelmann M, Muhlemann K: Substantially enhanced cloning efficiency of SAGE (Serial Analysis of Gene Expression) by adding a heating step to the original protocol. Nucleic Acids Res 1999, 27:917-918.

38. Hsu EM, McNicol PJ, Guijon FB, Paraskevas M: Quantification of HPV-16 E6-E7 transcription in cervical intraepithelial neoplasia by reverse transcriptase polymerase chain reaction. Int J Cancer 1993, 55:397-40I.

39. Primerquest program [http://www.idtdna.com]
Publish with BioMed Central and every scientist can read your work free of charge

"BioMed Central will be the most significant development for disseminating the results of biomedical research in our lifetime. "

Sir Paul Nurse, Cancer Research UK

Your research papers will be:

- available free of charge to the entire biomedical community

- peer reviewed and published immediately upon acceptance

- cited in PubMed and archived on PubMed Central

- yours - you keep the copyright
BioMedcentral 